Nama : Maulana Muhammad

NIM : 1710111310006

\title{
PENGARUH PENERAPAN MODEL INQUIRY BASED LEARNING TERHADAP KEMAMPUAN BERPIKIR KRITIS PESERTA DIDIK PADA MATERI PROKLAMASI DAN PROSES TERBENTUKNYA NKRI DI SMAN 1 AMUNTAI KELAS 12 IPS 3
}

\section{A. Latar Belakang}

Salah satu mata pelajaran yang menuntut kemampuan berpikir siswa adalah mata pelajaran sejarah. Menurut Ismaun dalam Abdullah Taufik sejarah adalah pengetahuan tentang kisah mengenai peristiwa-peristiwa yang benar-benar terjadi atau berlangsung dalam segala aspeknya pada masa lampau. Sejarah merupakan catatan atau rekaman pilihan yang disusun secara teliti tentang segala aspek kehidupan umat manusia pada masa lampau. Jadi pembelajaran sejarah berarti mempelajari peristiwaperistiwa pada masa lampau untuk dijadikan pengalaman guna memperoleh kehidupan yang lebih baik. Melalui pembelajaran sejarah diharapkan peserta didik mampu mengembangkan potensi untuk berpikir secara kronologis dan memiliki pengetahuan tentang masa lampau yang dapat digunakan untuk memahami dan menjelaskan proses perkembangan dan perubahan masyarakat. Pembelajaran sejarah juga berguna sebagai acuan untuk cara berpikir dan bertindak pada masa yang akan datang supaya hal buruk yang sudah terjadi pada masa lampau tidak terjadi lagi jika kita dapat mengantisipasinya.

Pembelajaran sejarah mulai diajarkan pada peserta didik sejak duduk di bangku sekolah dasar secara bertahap. Sejarah diajarkan lebih umum di sekolah dasar kemudian materi sejarah lebih diperdalam kembali pada sekolah menengah pertama dan atas. Salah satu tujuan pembelajaran sejarah menurut Kemendikbud (2015, hlmn. 11) yaitu mengembangkan kemampuan berpikir historis (historical thinking) yang menjadi dasar untuk kemampuan berpikir logis, kreatif, inspiratif dan inovatif melalui proses inquiry ilmiah. Pendidikan yang mampu mendukung sumber daya manusia pada usia produktif yang melimpah dapat ditransformasikan menjadi sumber daya manusia yang memiliki kompetensi dan keterampilan melalui pendidikan yang mengembangkan potensi peserta didik.

Belajar adalah suatu proses yang kompleks yang terjadi pada semua orang dan berlangsung seumur hidup, sejak dia masih bayi hingga ke liang lahat nanti. Salah satu pertanda bahwa seseorang telah belajar sesuatu adalah adanya perubahan tingkah laku dalam dirinya. Perubahan tingkah laku tersebut menyangkut baik perubahan yang bersifat pengetahuan (kognitif) dan keterampilan (psikomotor) maupun yang menyangkut nilai dan sikap (afektif) (Sadiman, 2011: 2).

Melihat pentingnya Sejarah dan peranannya dalam pendidikan, maka peningkatan mutu pendidikan harus selalu diupayakan. Salah satu kecakapan hidup 
(life skill) yang perlu dikembangkan melalui proses pendidikan adalah keterampilan berpikir (Depdiknas, 2003: 20). Oleh karena itu pendidik dalam merancang persiapan mengajar perlu menyusun strategi pembelajaran yang dirancang secara seksama sesuai dengan tujuan pembelajaran untuk mencapai hasil belajar peserta didik yang optimal (Sanjaya, 2006: 128).

Saat ini kemampuan berpikir kritis dirasakan perlu dalam kegiatan pembelajaran karena segala informasi global masuk dengan mudah, hal tersebut menyebabkan selain informasi yang bersifat baik ataupun buruk akan terus mengalir tanpa henti dan dapat mempengaruhi sifat mental anak. Maka dari itu, diperlukan suatu kemampuan berpikir kritis dengan jelas dan imajinatif, menilai bukti, bermain logika dan mencari alternatif untuk menemukan suatu solusi, memberi anak sebuah rute yang jelas di tengah kekacauan pemikiran pada zaman teknologi dan globalisasi saat ini (Johnson, 2007: 187).

Dalam kaitannya dengan kompetensi dasar kelas XII yaitu menganalisis peristiwa sekitar proklamasi 17 Agustus 1945 dan pembentukan pemerintahan Indonesia maka materi tersebut lebih menuntut melibatkan aktivitas dan berpikir kritis peserta didik dalam proses pembelajaran. Materi pokok Proklamasi Dan Proses Terbentuknya NKRI memuat tentang peristiwa-peristiwa sekitar Proklamasi Kemerdekaan 17 Agustus 1945 dan Pembentukan Kelengkapan Negara.

Dalam proses pembelajaran, nampaknya belum banyak pendidik yang menciptakan kondisi dan situasi yang memungkinkan peserta didik untuk melakukan proses berpikir kritis. Hal tersebut juga sesuai dengan hasil observasi dan diskusi dengan pendidik yang mengajar Sejarah di SMAN 1 AMUNTAI kelas 12 IPS 3, diketahui bahwa pendidik masih menggunakan model pembelajaran langsung dengan metode ceramah dan tanya jawab. Selama ini pendidik kurang memberdayakan aktivitas dan kemampuan berpikir kritis secara optimal khususnya pada materi Proklamasi Dan Proses Terbentuknya NKRI.

"Pada dasarnya siswa bukanlah botol kosong yang harus terus diisi hingga penuh oleh guru, melainkan botol yang sudah berisi. Tugas guru adalah mengoptimalkan bakat dan minat serta kemampuan para siswa" (Sukadi, 2006:2930).Jadi, perlu adanya kesempatan yang diberikan kepada peserta didik untuk membangun wacana dari pengetahuan awal yang dimilikinya. Keterlibatan peserta didik dalam membangun pengetahuan akan menghasilkan daya serap yang lebih baik. Seperti yang diungkapkan Dryden dan Vos (1999) yang dikutip dari buku Prawiradilaga, "Belajar yang dilakukan dengan membaca memiliki daya serap sebanyak 10\%, mendengar 20\%, melihat 30\%, melihat dan mendengar sebanyak 50\%, mengatakan 70\%, serta mengatakan sambil mengerjakan 90\%" (Prawiradilaga, 2009:20).

Kaitannya dengan pembelajaran sejarah pada saat ini masih banyak menggunakan pembelajaran tradisional, baik ceramah atau eksplanasi yaitu penjelasan biasa, yang di dalamnya belum cukup memberikan gambaran yang luas dan menyeluruh, akibatnya siswa tidak memiliki pemahaman yang konkrit tentang 
sejarah yang bisa diaplikasikan dalam kehidupan sehari-hari. Bagi sebagian siswa mata pelajaran sejarah merupakan mata pelajaran yang membosankan karena guru hanya bercerita sedangkan siswa hanya duduk dan mendengarkan, sehingga kegiatan belajar mengajar menjadi kurang menarik dan membosankan. Pembelajaran yang terjadi bersifat transfer of knowledge, yang berarti siswa dipandang sebagai kertas putih yang perlu di tulisi dengan sejumlah ilmu pengetahuan. Hal ini sangat berbanding terbalik dengan Kurikulum yang telah di terapkan pada akhir-akhir ini, di mana peserta didik yang di tuntut untuk aktif bukan hanya mengandalkan pengetahuan ataupun informasi dari guru saja. Ketika seorang guru menerapkan metode yang ceramah yang monoton selama jam pelajaran secara penuh maka seorang guru akan menjadi pusat kegiatan pembelajaran yang mendominasi kegiatan belajar mengajar yang sedang berlangsung, maka peserta didik hanya menerima informasi yang di dapat dengan mencatat informasi di buku tulis masing-masing. Akhirnya metode belajar yang digunakan oleh peserta didik adalah metode menghafal sehingga ilmu yang mereka peroleh tidak tertanam dengan kuat dan cenderung mudah untuk dilupakan. Sehubungan dengan hal itu maka tujuan pembelajaran yang dirancang akan sulit untuk dicapai dan pembelajaran sejarah cenderung membosankan karena kurangnya motivasi dan partisipasi peserta didik. Selain itu, proses pembelajaran yang terjadi belum memaksimalkan siswa baik fisik maupun psikisnya untuk dapat menyerap lebih banyak informasi dan belum memperhatikan keterampilan berfikir siswa. Dalam proses pembelajaran di kelas terlalu fokus pada aspek pengetahuan saja. Pengetahuan siswa hanya dipenuhi berbagai pengertian secara faktual dan konseptual, pengetahuan siswa hanya dalam bentuk ingatan dan hafalan. Akibatnya, kemampuan siswa dalam pembelajaran sejarah hanya terbatas sampai pada kemampuan menghafalkan sekumpulan fakta yang disajikan guru tidak mengarah kepada pemahaman metakognitif.

Penggunaan model pembelajaran yang tepat dapat mendorong tumbuhnya rasa senang siswa terhadap pelajaran, menumbuhkan dan meningkatkan motivasi dalam mengerjakan tugas, memberikan kemudahan bagi siswa untuk memahami pelajaran, meningkatkan motivasi siswa sehingga memungkinkan siswa mencapai hasil belajar yang lebih baik. Oleh karena itu untuk merubah pandangan siswa mengenai sejarah serta menarik minat siswa dalam belajar sejarah maka perlu adanya inovasi baru yang perlu dikembangkan dan diterapkan oleh guru dan sekolah salah satunya yaitu dalam penggunaan metode mengajar. Dengan menggunakan model pembelajaran yang tepat, dapat meningkatkan minat siswa terhadap pembelajaran sejarah.

Salah satu model pembelajaran yang memberikan banyak kesempatan untuk mengembangkan aktivitas dan kemampuan berpikir kritis peserta didik adalah model inquiry based learning. Model inquiry didefinisikan sebagai suatu rangkaian kegiatan belajar yang melibatkan secara maksimal seluruh kemampuan peserta didik untuk mencari dan menyelidiki masalah secara sistematis, kritis, logis, dan analisis sehingga mereka dapat merumuskan sendiri penemuan mereka dengan rasa percaya diri. Pembelajaran inquiry menekankan pada proses berpikir yang bersandarkan kepada proses belajar dan hasil belajar serta tidak hanya mengembangkan keterampilan intelektual peserta didik, tetapi juga aktivitas belajar peserta didik pada proses pembelajaran. (Carin dan Sund dalam Ahmadi, 2005: 108). 
Dari pernyataan tesebut maka mengunakan model inquiry dapat membangkitkan motivasi dan merangsang kegiatan belajar. Diharapkan dengan menggunakan model inquiry ini aktivitas dan hasil belajar peserta didik akan lebih baik dibandingkan dengan menggunakan media yang lain.

Hasil penelitian Winarni dalam Masitoh (2009: 72) menunjukkan bahwa melalui inquiry peserta didik dapat dikondisikan untuk berpikir kritis, dari observasi yang peserta didik lakukan dapat memunculkan suatu kesimpulan sehingga peserta didik dapat menemukan konsep sendiri secara ilmiah. Pengetahuan akan melekat lebih lama apabila peserta didik dilibatkan secara langsung dalam proses pembelajaran. Berdasarkan uraian di atas, penggunaan model inquiry based learning diduga dapat meningkatkan aktivitas dan kemampuan berpikir kritis peserta didik. Dengan demikian penulis tertarik untuk melakukan penelitian dengan judul Pengaruh Penerapan Model Inquiry Based Learning Terhadap Peningkatan Aktivitas Dan Kemampuan Berpikir Kritis Peserta Didik Pada Materi Proklamasi Dan Proses Terbentuknya NKRI Di SMAN 1 AMUNTAI Kelas 12 IPS 3.

\section{B. Identifikasi Masalah}

1. Metode yang digunakan dalam pembelajaran sejarah masih berpusat pada guru.

2. Kurangnya kegiatan yang melibatkan siswa.

3. Kurangnya motivasi dan minat siswa terhadap pembelajaran sejarah .

\section{Batasan Masalah}

Batasan masalah yang dapat di ambil dari identifikasi masalah tersebut adalah:

1. Penelitian dilakukan pada mata pelajaran sejarah di kelas materi Proklamasi Dan Proses Terbentuknya NKRI Di SMAN 1 AMUNTAI Kelas 12 IPS 3.

2. Model pembelajaran yang digunakan dalam penelitian ini yaitu model Inkuiry Based Learning .

3. Hasil belajar yang dinilai adalah kemampuan kognitif siswa yang tercermin dari hasil tes yang dilakukan pada akhir penelitian .

\section{Rumusan Masalah}

1. Adakah pengaruh penerapan model Inquiry Based Learning (IBL) dalam meningkatkan aktivitas belajar peserta didik pada materi Proklamasi Dan Proses Terbentuknya NKRI Di SMAN 1 AMUNTAI Kelas 12 IPS 3 ?

2. Adakah pengaruh penerapan model IBL dalam meningkatkan kemampuan berpikir kritis peserta didik pada materi Proklamasi Dan Proses Terbentuknya NKRI Di SMAN 1 AMUNTAI Kelas 12 IPS 3 ?

\section{E. Tujuan}

Sesuai dengan permasalahan yang telah dikemukakan di atas, maka tujuan penelitian ini adalah menganalisis pengaruh penerapan model IBL dalam meningkatkan kemampuan berpikir kritis peserta didik pada materi Proklamasi Dan Proses Terbentuknya NKRI Di SMAN 1 AMUNTAI Kelas 12 IPS 3.

\section{F. Manfaat}

Manfaat yang diharapkan dari penelitian ini yaitu: 
1. Teoritis.

Bagi penulis dapat menambah pengetahuan penulis sebagai calon pendidik dalam pembelajaran sejarah dengan memilih metode pembelajaran yang sesuai atau yang lebih efektif.

2. Praktis.

a. Bagi Guru

1) Guru memperoleh pengalaman untuk meningkatkan keterampilan memilih strategi pembelajaran yang bervariasi.

2) Sebagai bahan informasi guru atau pendidik dalam memilih pendekatan atau metode pembelajaran yang lebih tepat dengan melibatkan partisipasi aktif siswa.

3) Dapat memperbaiki dan meningkatkan sistem pembelajaran di kelas.

4) Guru termotivasi untuk melakukan analisis sederhana yang bermanfaat bagi perbaikan dalam proses pembelajaran serta meningkatkan kemampuan diri sendiri.

b. Bagi Siswa

1) Dapat menumbuhkan kemampuan siswa dalam memecahkan masalah baik secara individu maupun kelompok pada mata pelajaran sejarah.

2) Siswa dapat belajar lebih aktif dalam belajar dengan car belajar mandiri yang dapat menumbuhkan prestasi belajar.

3) Mengatasi kejenuhan siswa dalam penyerapan materi khususnya mata pelajaran sejarah.

4) Siswa lebih berfikir kritis dan kreatif.

c. Bagi Dunia Pendidikan

1) Hasil penelitian diharapkan dapat memberi sumbang saran dalam penerapan metode pembelajaran yang sesuai dalam memajukan dunia pendidikan.

2) Dapat digunakan sebaga referensi atau bahan kajian dalam menambah khasanah ilmu pengetahuan dibidang pendidikan. 


\section{BAB II \\ KAJIAN TEORI}

\section{A. Pengertian Model Inquiry Based Learning}

Kata "Inquiry" berasal dari bahasa inggris yang berarti mengadakan penyelidikan, menanyakan keterangan, melakukan pemeriksaan (Echols dan Hassan Shadily, 2003: 323). Sedangkan menurut Gulo (2005:84) inkuiri berarti pertanyaan atau pemeriksaan, penyelidikan. Sumantri (1999:164), menyatakan bahwa metode inquiry adalah cara penyajian pelajaran yang memberi kesempatan kepada peserta didik untuk menemukan informasi dengan atau tanpa bantuan guru.

Metode inquiry berupaya menanamkan dasar-dasar berpikir ilmiah pada diri siswa, dan menempatkan siswa dalam suatu peran yang menuntut inisiatif besar dalam menemukan hal-hal penting untuk dirinya sendiri. Menurut Carin and Sund dalam Ahmadi (2005:108), metode inquiry didefinisikan sebagai suatu rangkaian kegiatan belajar yang melibatkan secara maksimal seluruh kemampuan siswa untuk mencari dan menyelidiki masalah secara sistematis, kritis, logis, dan analisis sehingga mereka dapat merumuskan sendiri penemuan mereka dengan rasa percaya diri.

Kata "Inquiry" berasal dari Bahasa Inggris yang berarti mengadakan penyelidikan, menanyakan keterangan, melakukan pemeriksaan" (Echols dan Hassan Shadily, 2003: 323). Sedangkan menurut "Gulo (2005:84) inkuiri berarti pertanyaan atau pemeriksaan, penyelidikan".

Alfred Novak (Haury, 1993) mendefinikan bahwa "inquiry merupakan usaha manusia untuk menjelaskan secara rasional fenomena-fenomena yang memancing rasa ingin tahu". Dengan kata lain, inquiry berkaitan dengan aktivitas dan keterampilan aktif pencarian pengetahuan untuk memuaskan rasa ingin tahu (Haury, 1993).

Pendekatan IBL adalah suatu pendekatan yang digunakan dan mengacu pada suatu cara untuk mempertanyakan, mencari pengetahuan (informasi), atau mempelajari suatu gejala. Pembelajaran dengan pendekatan IBL selalu mengusahakan agar siswa selalu aktif secara mental maupun fisik. Materi yang disajikan guru bukan begitu saja diberitahukan dan diterima oleh siswa, tetapi siswa diusahakan sedemikian rupa sehingga mereka memperoleh berbagai pengalaman dalam rangka "menemukan sendiri" konsep-konsep yang direncanakan oleh guru.

Inquiry Based Learning (IBL) adalah sebuah teknik mengajar di mana guru melibatkan siswa di dalam proses belajar melalui penggunaan cara-cara bertanya, aktivitas problem solving, dan berpikir kritis. Hal ini akan memerlukan banyak waktu dalam persiapannya. Inquiry Based Learning biasanya berupa kerja kolaboratif. Kelas dibagi ke dalam kelompok-kelompok kecil. Setiap kelompok diberi sebuah pertanyaan atau permasalahan yang akan mengarahkan semua anggota kelompok bekerja bersama mengembangkan proyek berdasarkan pertanyaan tersebut untuk menemukan jawabannya. Karena inquiry based learning berbasis pertanyaan, maka guru harus menyiapkan pertanyaan yang bersifat terbuka sehingga siswa dapat mengembangkan pikirannya. Siswa harus diberi kesempatan untuk mencoba menemukan sendiri konsep yang diajarkan. Lebih dari itu, jika siswa juga diberi kesempatan untuk mengukur kemajuan belajarnya sendiri, maka hal ini akan membantu mereka belajar. 


\section{B. Kajian Teori}

\section{Pembelajaran Menurut Konsep Teori Belajar}

Pembelajaran secara umum dalam psikologi pendidikan didefinisikan sebagai suatu proses yang menyatukan kognitif, emosional, pengalaman dan pengaruh lingkungan untuk memperoleh, meningkatkan, atau membuat perubahan pengetahuan, sikap, keterampilan, nilai dan pandangan dunia. Pembelajaran sebagai suatu proses berfokus pada apa yang terjadi ketika belajar berlangsung. Penjelasan apa itu pembelajaran menjadi kajian dalam teori-teori belajar.

Secara umum teori-teori belajar dapat dikelompokkan menjadi lima aliran utama, yaitu Teori Belajar Behaviorisme, Teori Belajar Kognitif, Teori Belajar Humanisme, Teori Belajar Konstruktivisme, dan Teori Belajar Sibernetik yang merupakan teori belajar yang paling baru.

Teori pembelajaran Behaviorisme didasarkan pada asumsi bahwa: (1) hasil belajar adalah berupa perubahan tingkah laku yang dapat diobservasi; (2) tingkah laku dan perubahan tingkah laku sebagai hasil belajar dimodifikasi oleh kondisikondisi lingkungan; (3) komponen teori behavioral ini adalah stimulus, respon, dan konsekuensi; (4) faktor penentu yang penting sebagai kondisi lingkungan dalam belajar adalah reinforcement (pembiasaan secara terus menerus).

Teori belajar kognitif didasarkan pada asumsi: (1) individu mempunyai kemampuan mengolah informasi; (2) kemampuan memperoleh informasi tergantung pada factor kognitif yang berkembang sesuai dengan perkembangan usia; (3) belajar adalah proses internal yang kompleks berupa pemrosesan informasi; (4) hasil belajar adalah perubahan kognitif; (5) cara belajar pada anak dan orang dewasa berbeda sesuai tahap perkembangannya.

Teori belajar humanisme didasarkan pada asumsi: (1) individu adalah pribadi utuh, ia mempunyai mempunyai kebebasan memilih untuk menentukan kehidupannya; (2) individu mempunyai hasrat untuk mengetahui, bereksplorasi dan mengasimilasi pengalaman-pengalamannya; (3) belajar adalah fungsi seluruh kepribadian individu; (4) belajar akan bermakna jika melibatkan seluruh kepribadian individu.

Teori belajar Konstruktivisme mempunyai ciri-ciri sebagai berikut yaitu: (1) Pengetahuan dibangun oleh siswa sendiri; (2) pengetahuan tidak dapat dipindahkan dari guru ke siswa, kecuali hanya dengan keaktifan sendiri siswa dalam proses belajar; (3) siswa mengkonstruksi secara terus menerus, sehingga selalu terjadi perubahan konsep ilmiah, dan (4) guru menjadi fasilitator untuk membantu menyediakan sarana prasarana, situasi dan kondisi agar proses konstruksi berjalan lancar.

\section{Teori Strategi Pembelajaran}

Kata strategi berasal dari bahasa Latin "strategia”yang diartikan sebagai seni penggunaan rencana untuk mencapai tujuan. Oleh karena itu, strategi pembelajaran terdiri atas semua komponen materi pembelajaran dan prosedur yang akan digunakan untuk membantu siswa mencapai tujuanpembelajaran tertentu.

Teori yang melandasi strategi pembelajaran ada tiga yaitu: (1) Advance organizer dari Ausabel, (2) Discovery Learning dari Bruner, dan (3) Peristiwaperistiwa belajar bermakna dari Gagne. Advance Organizer dari Ausabel merupakan pernyataan pengantar yang membantu siswa untuk mempersiapkan kegiatan pembelajaran baru dan menunjukkan hubungan antara materi yang akan dipelajari dengan konsep atau ide yang lebih luas. Discovery Learning dari Bruner adalah pembelajaran dimulai dari suatu masalah untuk meningkatkan kemampuan 
siswa meneliti permasalahan tersebut secara ilmiah. Pembelajaran peristiwaperistiwa belajar bermakna Gagne menekankan pada ekspositori dengan cara guru menyajikan materi pembelajaran secara eksplisit dan terorganisasi, sehingga siswa menerima rangkaian ide tersebut secara efektif dan efisien.

\section{Kerangka Berpikir}

Kerangka berpikir dalam penelitian ini dapat digambarkan sebagai berikut :

\section{Kondisi Awal Pembelajaran}

Metode yang digunakan dalam pembelajaran sejarah masih berpusat pada guru, kurangnya kegiatan yang melibatkan siswa., dan kurangnya motivasi dan minat siswa terhadap pembelajaran sejarah .

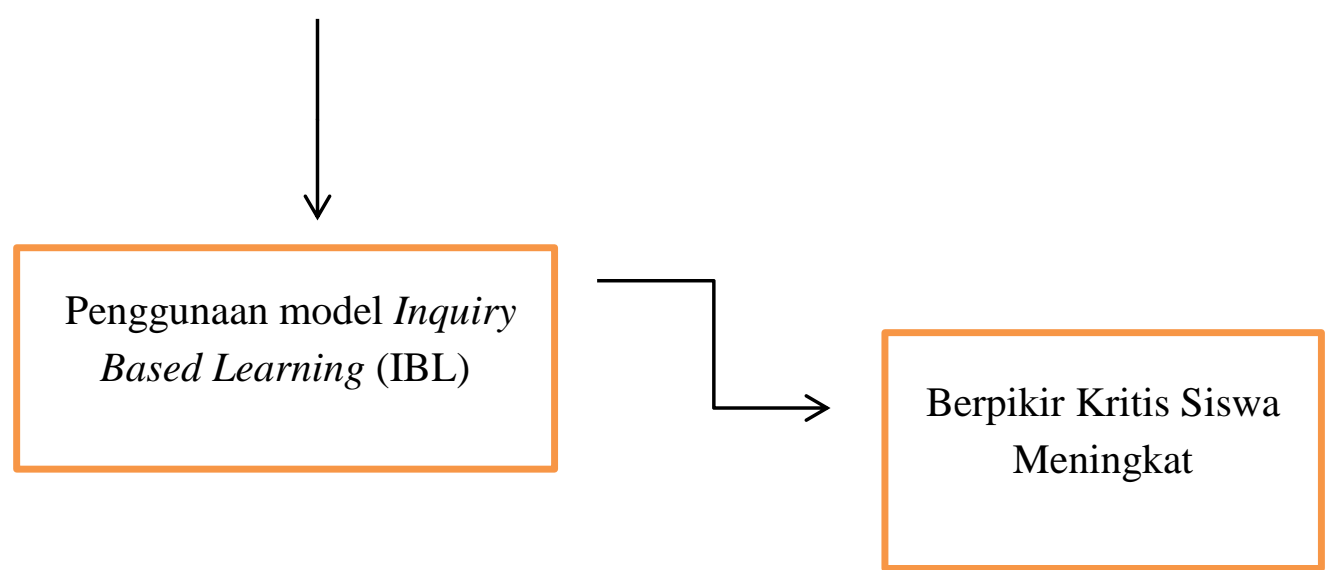

\section{Hipotesis Penelitian}

Dengan Hipotesa penelitian berdasarkan permasalahan dan deskripsi teoritis di atas yaitu dengan penerapan metode Pembelajaran Inquiry dapat meningkatkan prestasi belajar Peserta Didik Pada Materi Proklamasi Dan Proses Terbentuknya NKRI Di SMAN 1 AMUNTAI Kelas 12 IPS 3. 


\section{BAB III}

\section{METODE PENELITIAN}

\section{A. Jenis Penelitian}

Penelitian ini merupakan Penelitian Tindakan Kelas model Kemmis dan Mc. Taggart yang terdiri dari empat tahap yaitu: 1) perencanaan, 2) pelaksanaan, dan 3) observasi 4) refleksi. Keempat tahapan dalam penelitian ini merupakan unsur untuk membentuk sebuah siklus, yaitu satu putaran kegiatan beruntun yang kembali kelangkah semula atau siklus berulang.

\section{B. Tempat dan Waktu Penelitian}

Penelitian ini bertempat di kelas XII SMA Negeri 1 Amuntai Kabupaten Hulu Sungai Utara dan dilaksanakan pada tanggal 04 dan 16 bulan Desember 2020.

\section{Subjek Penelitian}

Subjek penelitian ini adalah siswa kelas XII SMA Negeri 1 Amuntai tahun ajaran 2019/2020, yang mana dalam kelas tersebut siswanya berjumlah 30 orang terdiri dari 17 siswa laki-laki dan 13 siswa perempuan.

\section{Populasi dan Sampel}

1. Populasi

Menurut Sutrisno Hadi (1985 : 20) populasi adalah seluruh individu yang dimaksud untuk diselidiki, sedangkan menurut Suharsimi Arikunto (2002 : 115) mengatakan bahwa populasi adalah keseluruhan subjek penelitian. Dalam penelitian ini populasinya adalah Siswa dan Siswi kelas XII IPS 3 SMAN 1 Amuntai tahun ajaran 2019/2020.

2. Sampel

Menurut Sugiyono (2012: 81) sampel adalah bagian dari jumlah dan karakteristik yang dimiliki oleh populasi tersebut. Bila populasi besar, dan peneliti tidak mungkin mempelajari semua yang ada pada populasi, misalnya karena keterbatasan dana, tenaga dan waktu, maka peneliti dapat menggunakan sampel yang diambil dari populasi itu. Sampel dalam penelitian ini berjumlah 30 orang.

\section{E. Variabel Penelitian}

Dalam penelitian ini ada dua variabel yaitu variabel Pengaruh Penerapan Model Inquiry Based Learning (X1) sebagai variabel bebas Terhadap Peningkatan Aktivitas Dan Kemampuan Berpikir Kritis (X2) sebagai variabel terikat.

\section{F. Instrumen Penelitian}

Berdasarkan bentuk desain penelitian, pengumpulan data dilakukan menggunakan metode tes. Menurut Muliawan (2014:191), tes merupakan teknik pengumpulan data dimana subjek yang diteliti diminta mengerjakan tugas tertentu dalam bentuk tertulis, lisan, maupun praktik. Pada penelitian ini, tes yang digunakan adalah tes tertulis dengan instrumen berbentuk soal berbentuk tes objektif (multiple choice), lembar observasi kinerja guru dan lembar observasi keaktifan siswa. Instrumen dibuat sesuai dengan indikator pencapaian kompetensi dan tujuan 
pembelajaran yang terdapat pada kisi-kisi agar tidak menyimpang dari materi pembelajaran. Instrument pengumpulan data yang digunakan dalam penelitian ini yaitu:

a. Lembar observasi

Lembar observasi yang digunakan ada dua macam:

1. Lembar observasi siswa

Lembar observasi siswa digunakan untuk mengetahui aktivitas siswa selama kegiatan pembelajaran berlangsung.

2. Lembar observasi guru

Lembar observasi diisi oleh seorang observer guna mengamati kegiatan peneliti dalam penerapan Model Inkuiri .

b. Lembar tes

Test merupakan alat yang digunakan untuk mengukur kemampuan siswa dalam memahami dan menguasai materi yang sudah dipelajari.

\section{G. Teknik Pengumpulan Data}

Data yang dikumpulkan untuk dianalisis dalam penelitian ini adalah :

1. Data hasil belajar siswa diperoleh dari hasil evaluasi dengan menggunakan tes yang telah disiapkan.

2. Data mengenai aktivitas siswa diperoleh dengan menggunakan metode observasi yang diisi oleh guru ketika proses pembelajaran berlangsung dan dituliskan di lembar observasi yang telah dibuat. Sedangkan, data aktivitas guru dalam mengajar diisi oleh teman sejawat, mengamati dan melihat kekurangan-kekurangan pada saat proses pembelajaran berlangsung.

\section{H. Teknik Analisis Data}

A. Analisis Data Observasi.

Untuk menganalisis data observasi dilakukan secara deskriptif dengan menghitung rata-rata skor pengamat (Sudjana, 2004). Data observasi yang diperoleh digunakan untuk merefleksi tindakan yang telah dilakukan dan diolah secara deskriptif dengan menghitung:

Rata-rata skor $=\frac{\text { Jumlah Skor }}{\text { Jumlah Observer }}$

Skor tertinggi $=$ Jumlah butir observasi $\mathrm{x}$ skor tertinggi tiap butir

Skor terendah $=$ Jumlah butir observasi $\mathrm{x}$ skor terendah tiap butir

Selisih skor $=$ Skor tertinggi - skor terendah

Kisaran nilai untuk tiap kriteria $=\frac{\text { selisih } \text { skor }}{\text { jumlah } \text { kriteria penilaian }}$

a. Observasi aktivitas guru

Skor tertinggi untuk tiap butir observasi 3. Jumlah aspek observasi guru 11 maka:

Skor tertinggi $=11 \times 3=33$

Skor terendah $=11 \times 1=11$

Selisih skor $=33-11=22$

Kisaran nilai untuk tiap kriteria $=\frac{22}{3}=7,3$

Hasil kisaran nilai untuk tiap kategori pengamatan observasi guru dituliskan dalam tabel sebagai berikut. 


\begin{tabular}{|l|c|c|}
\hline NO & Skor & Kriteria \\
\hline 1. & $11-18$ & Kurang \\
\hline 2. & $20-26$ & Cukup \\
\hline 3. & $27-33$ & Baik \\
\hline
\end{tabular}

b. Observasi Aktifitas Siswa

Skor tertinggi tiap butir observasi 3. Jumlah butir observasi 11 maka:

Skor tertinggi $=11 \times 3=33$

Skor terendah $=11 \times 1=11$

Selisih skor $=33-11=22$

Kisaran nilai untuk tiap kriteria $=\frac{22}{3}=7,3$

Hasil kisaran nilai untuk tiap kategori pengamatan observasi siswa dituliskan dalam tabel sebagai berikut.

\begin{tabular}{|c|c|c|}
\hline NO & Skor & Kriteria \\
\hline 1. & $11-18$ & Kurang \\
\hline 2. & $20-26$ & Cukup \\
\hline 3. & $27-33$ & Baik \\
\hline
\end{tabular}

B. Analisis Data Hasil Belajar

Data tes dianalisis dengan menggunakan rata-rata nilai dan persentase ketuntasan belajar, dimana secara klasikal proses pembelajaran dikatakan tuntas menurut Depdiknas 2006 apabila 85\% siswa di kelas memperoleh nilai $\geq 70$ berdasarkan KKM sekolah, sedangkan proses pembelajaran dikatakan tuntas secara individual apabila siswa memperoleh nilai $\geq 70$. Untuk mengetahui persentase ketuntasan belajar digunakan rumus :

Nilai rata-rata $=\frac{\delta x}{N}$

Keterangan : $\quad \underline{\delta x}=$ Jumlah nilai

$$
\mathrm{N}=\text { Jumlah siswa }
$$

Persentase ketuntasan belajar $=\frac{N S}{N} \times 100 \%$

Keterangan :

$\mathrm{NS}=$ Jumlah siswa yang mencapai nilai $\geq 70$

$\mathrm{N}=$ Jumlah seluruh siswa

\section{Indikator Keberhasilan}

Ketuntasan belajar ditandai apabila hasil belajar siswa sebagai berikut:

Untuk individu : jika siswa mendapat nilai $\geq 70$

Untuk klasikal : jika 85\% siswa mendapat nilai $\geq 70$

Keaktifan siswa : jika siswa mendapat skor 27-33

Keaktifan guru : jika guru mendapat skor 27-33 


\section{DAFTAR PUSTAKA}

Ahmadi, A. 2005. Strategi Belajar Mengajar. Pustaka Setia. Bandung.

Apriliana, D. N. S. (2017). PENGGUNAAN MODEL PEMBELAJARAN KOOPERATIF TIPE QUICK ON THE DRAW DALAM PEMBELAJARAN SEJARAH UNTUK MENUMBUHKAN KERJA SAMA SISWA (Doctoral dissertation, Universitas Pendidikan Indonesia).

Depdiknas. 2003. Kurikulum 2004 Standar Kompetensi Sekolah Dasar. Depdiknas. Jakarta.

Depdiknas. (2006). Berbagai Pendekatan dan Model Dalam Pembelajaran. Jakarta : Ditjen Dikdasmen. Direktorat Pendidikan Lanjutan Pertama.

Echols, John M. Dan Hasan Shadily, Kamus Inggris Indonesia. Jakarta : Gramedia Pustaka Utama, 2003.

Gulo, W. (2005). Strategi Belajar Mengajar. Jakarta : PT Gramedia Widiasarana Indonesia.

Johnson, E B. 2007. Contextual Teaching and Learning. MLL. Bandung.

Haury, D.L. (1993). Teaching Science Through Inquiry. London: David Fulton Publisher Ltd.

Kemendikbud (2015) Materi Pelatihan Guru Implementasi Kurikulum 2013: SMA/MA dan SMK/MAK Sejarah Indonesia. Jakarta : Badan Pengembangan SDM dan Kementerian Pendidikan dan Kebudayaan.

Masitoh, I.D. Marjonodan Joko. 2017. Pengaruh Model Pembelajaran Inkuiri Terbimbing Terhadap Kemampuan Berpikir Kritis. Skripsi. Universitas Sebelas Maret. Surakarta.

Masruroh, A. (2017). Pengaruh Model Pembelajaran Inquiry Training Terhadap Kemampuan Berpikir Kritis Siswa Siswa Pada Mata Pelajaran Sejarah Siswa Kelas X Di SMA Negeri 12 Surabaya. Avatara, 5(3).

Prawiradilaga, Dewi Salma. 2009. Prinsip Desain Pembelajaran. Jakarta: Kencana Prenada Media Grup.

Sanjaya, W. 2006. Strategi Pembelajaran. Kencana Prenada Media Group. Jakarta.

Sardiman, AM. 1996. Interaksi dan Motivasi Belajar Mengajar. PT. Raja Grafindo Persada. Jakarta.

Sudjana, Nana. 2004. Dasar-dasar Proses Belajar Mengajar. Bandung : Sinar Baru Algensido Offset.

Sumantri, Permana M. (1999). Strategi Belajar Mengajar. Jakarta : Depdikbud Dirjen Dikti.

SUSANTO, Heri. Hubungan Pemahaman Sejarah Masa Revolusi Fisik Di Kalimantan Selatan Dan Persepsi Terhadap Keberagaman Budaya Di Kalimantan Selatan Dengan Sikap Nasionalisme Mahasiswa Program Studi Pendidikan Sejarah Fakultas 
Keguruan Dan Ilmu Pendidikan Universitas Lamb. 2011. PhD Thesis. UNS (Sebelas Maret University).

Susanto, Heri, and Helmi Akmal. "EFEKTIVITAS PENGGUNAAN APLIKASI PEMBELAJARAN BERBASIS MOBILE SMARTPHONE SEBAGAI MEDIA PENGENALAN SEJARAH LOKAL MASA REVOLUSI FISIK DI KALIMANTAN SELATAN PADA SISWA SEKOLAH MENENGAH ATAS."HISTORIA: Jurnal Program Studi Pendidikan Sejarah 6.2 (2018): 197-206.

Wiyati, Yuni, Tontowi Amsia, and M. Syaiful. "PENGARUH MODEL INQUIRY TERHADAP HASIL BELAJAR KOGNITIF SEJARAH SISWA." PESAGI (Jurnal Pendidikan dan Penelitian Sejarah) 3.5 (2015). 